\title{
Triazole-directed hydrogen-bonded structures of cationic iridium(III) complexes
}

\author{
Jeremy M. Rawson, ${ }^{* a}$ Loïc Donato, ${ }^{b}$ and Eli Zysman-Colman* ${ }^{c}$ \\ Received (in $X X X, X X X) X$ th $X X X X X X X X X 20 X X$, Accepted Xth $X X X X X X X X X 20 X X$ \\ ${ }_{5}$ DOI: 10.1039/b000000x
}

Despite the differing size of the $\mathrm{Cl}^{-}$and $\mathrm{PF}_{6}^{-}$counter-ions, the structures of the heteroleptic iridium(III) complexes, $\left[\operatorname{Ir}\left(\mathrm{dFphtl}_{2}(\mathrm{btl})\right] \mathrm{Cl},[1] \mathrm{Cl}\right.$, and $\left[\operatorname{Ir}(\mathrm{dFphtl})_{2}(\mathrm{btl})\right] \mathrm{PF}_{6},[1] \mathrm{PF}_{6}$, (where dFphtl = 1-Benzyl-4-(2,4-difluorophenyl)-1H-1,2,310 triazole and btl = 1,1'-Dibenzyl-4,4'-bi-1H-1,2,3-triazolyl) are found to exhibit similar morphologies in which both structures adopt hydrogen-bonded networks driven by the hydrogen-bond donor and acceptor demands of the triazole functional group. The triazole thus can be used as a 15 Supramolecular synthon to control the internuclear distance in the solid-state.

The 1,2,3-triazole ring is a ubiquitous building block in modern synthetic chemistry, ${ }^{1}$ which is readily constructed via the Huisgen azide-alkyne 1,3-dipolar cycloaddition reaction (Scheme 1). ${ }^{2}$ The

20 ability of this reaction to support a diversity of substituents has popularized the use of this reaction as one of the common 'click' reactions coined by Sharpless. ${ }^{3}$ Recently the structure-directing properties of the 1,2,3-triazole ring have been explored ${ }^{1}$ and, for example, anion-templating of the $\mathrm{C}(5)-\mathrm{H}$ group has been 25 implemented in organic catalysis, ${ }^{4}$ whilst intramolecular hydrogen bonding of the triazole unit has been utilised to enhance anion binding ${ }^{5}$ and as anion sensors inter alia. ${ }^{6}$

30
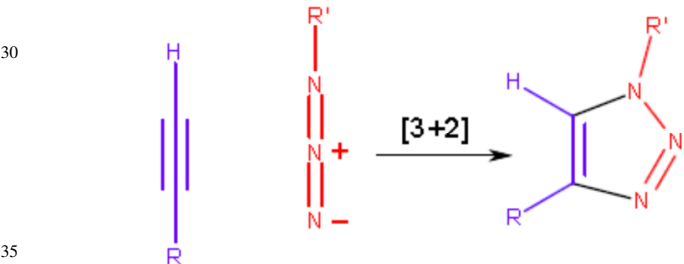

Scheme 1. Huisgen "Click" reaction

In recent years, the photo-physical properties of iridium(III) complexes have attracted particular attention as potential 40 components in organic light emitting diodes (OLEDs) and lightemitting electrochemical cells (LEECs). ${ }^{7}$ In OLEDs spacing of the individual emitter molecules is critical to performance; whilst high concentrations facilitate charge injection and transport, too high a concentration of emitters can lead to lower photo45 luminescent quantum yields $\left(\Phi_{\mathrm{PL}}\right)$ due to triplet-triplet annihilation and concentration quenching. ${ }^{8}$ Although LEECs operate on a different mechanism to OLEDs, here too performance can be affected by inter-nuclear spacing. ${ }^{9}$ For example, Shin and co-workers recently demonstrated that the 50 nature of the crystal packing had a direct impact on emission energies when comparing two polymorphs of the same neutral iridium(III) complex. ${ }^{10}$ Over the past several years, we have been exploring ${ }^{11}$ how the triazole motif, acting as a coordinating unit, influences the photo-physical properties of luminescent 55 iridium(III) complexes. ${ }^{12}$ In particular, we have targeted ionic iridium complexes as charged emitters in light-emitting electrochemical cells (LEECs) since their opto-electronic properties can be fine-tuned through ligand modification, whilst their ionic nature leads to enhanced thermal stability. Previously 60 it has been shown that the use of smaller counter-ions leads to less stable devices ${ }^{13}$ but with faster turn-on times. ${ }^{14}$ Recently, Bolink and co-workers also demonstrated that the nature of the counter-ion can dramatically affect LEEC performance. ${ }^{15}$ In their study of $[\operatorname{Ir}(\mathrm{ppy})(\mathrm{bpy})]^{+}$they showed how the chloride salt ${ }_{65}$ promotes hydrogen bonding to the aromatic protons at the 3 and 3 -positions of the ancillary 2,2'-bipyridine ligand and with the 5proton of one of the cyclo-metalating 2-phenylpyridine ligands, despite the fact that $\mathrm{C}-\mathrm{H}$ bonds are considered weak $\mathrm{H}$-bond donors. In addition, Deng and co-workers have shown how the 70 choice of counter-ion can have an impact on the emission quantum yield in the solid-state for a series of flexible organic fluorophores. ${ }^{16}$ They correlated these interactions to a large drop in performance of the device compared to the hexafluorophosphate salt. Clearly subtle changes to both cation 75 and anion affect crystal packing and device performance. Methods to control the solid-state architectures of such materials are therefore critical to future developments in this area. The work by Bolink indicates that strong non-covalent interactions might help direct the structures of such materials. ${ }^{15}$

${ }_{80}$ In the current manuscript we examine the propensity for the triazole ring to be involved in hydrogen bonding and find that the structures of two cationic iridium complexes $[1] \mathrm{Cl}$ and $[1]\left[\mathrm{PF}_{6}\right]$ (Scheme 2) appear to be dictated by the hydrogen-bonding motifs of the triazole units of the cation, suggesting the triazole unit can ${ }_{85}$ be utilised to control solid state architectures within this family of materials. Thus, despite changing $\mathrm{Cl}^{-}(r=1.67 \AA)$ to $\mathrm{PF}_{6}^{-}(r=1.80$ $\AA)$, several key features of the crystal packing are retained. 


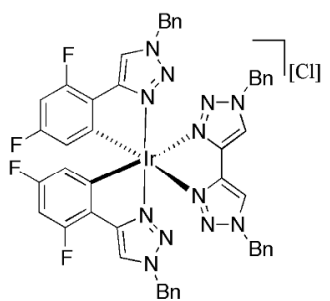

[1]Cl

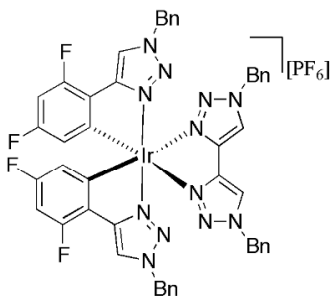

[1]PF 6
Scheme 2. Structures of $[1] \mathrm{Cl}$ and $[1] \mathrm{PF}_{6}$

\section{Results and Discussion}

The title complexes were obtained in two steps from $\mathrm{IrCl}_{3}$ through sequential addition of $\mathrm{dFphtl}$ and btl ligands $(\mathrm{dFphtl}=1$ 5 benzyl-4-(2,4-difluorophenyl)-1H-1,2,3-triazole and btl = 1,1'dibenzyl-4,4'-bi-1H-1,2,3-triazolyl). Solution state ${ }^{1} \mathrm{H}$ NMR reveals a significant downfield shift of the bistriazolyl proton signal for $[1] \mathrm{Cl}$ compared to $[1] \mathrm{PF}_{6}$ while the chemical environment of the triazolyl proton of the $\mathrm{C}^{\wedge} \mathrm{N}$ ligand is only 10 modestly perturbed (Fig. 1). The difference in solution ${ }^{1} \mathrm{H}$ NMR spectra of these two salts would indicate some degree of cationanion pairing in solution, despite the strongly polar nature of the $\mathrm{MeCN}$ solvent. The marked shift in the bis(triazolyl) $\mathrm{C}-\mathrm{H}$ peak is consistent with a C-H...CГ contact and which is reflected in the 15 solid state structure (vide infra).

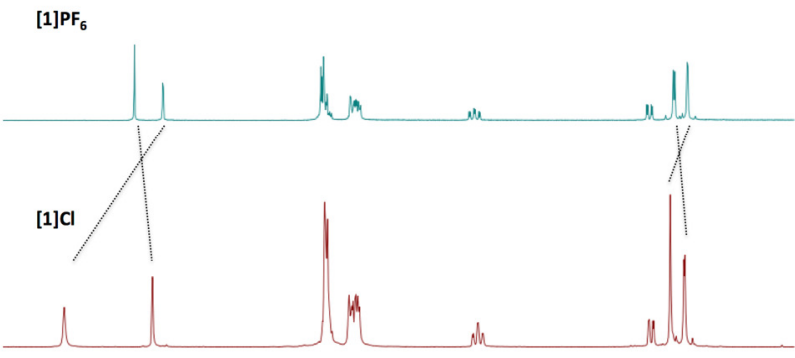

$\begin{array}{llllllllllllllllllllllllll}8.9 & 8.7 & 8.5 & 8.3 & 8.1 & 7.9 & 7.7 & 7.5 & 7.3 & 7.1 & 6.9 & 6.7 & 6.5 & 6.3 & 6.1 & 5.9 & 5.7 & 5.5 & 5.3 & 5.1\end{array}$

Figure 1. Aromatic region of the ${ }^{1} \mathrm{H}$ NMR for $[1] \mathrm{Cl}$ and $[1] \mathrm{PF}_{6}$ in $\mathrm{MeCN}-$ $d_{3}$ at $298 \mathrm{~K}$.

Crystals of $[\mathbf{1}] \mathrm{Cl}$ were obtained from a mixed solution of 20 propionitrile and tert-butyl methyl ether. Subsequent anion metathesis with aqueous $\mathrm{NH}_{4} \mathrm{PF}_{6}$ afforded [1] $\mathrm{PF}_{6}$, which was crystallised from a mixed solution comprising chloroform and ${ }^{i} \mathrm{Pr}_{2} \mathrm{O}$. Both salts are triclinic and crystalize in the space group $P$ 1 , crystallising as racemates with both $\Delta$ and $\Lambda$ isomers in the unit 25 cell related via the crystallographic inversion centre.

In both solid-state structures the iridium centres adopt a distorted octahedral coordination environment with the coordinating nitrogen atoms of the dFphtl mutually trans while the cyclometallating carbon atoms are disposed trans to the datively bound 30 nitrogen atoms of the btl ligand (Fig. 2, left). The cation geometries are nearly identical (Table 1; Fig. 2, right) with the geometry at the two Ir centres identical within experimental error (3 esd's). The largest deviations arise from small displacements in the positions of the benzyl groups of the dFPhtl ligands at the 35 periphery of the molecule. Notably these are rotated away from the btl, which is distinct from the conformation adopted in $\left[\operatorname{Ir}(\mathrm{dFphtl})_{2}(\mathrm{bpy})\right] \mathrm{PF}_{6}$ (bpy $=2,2^{\prime}$-bipyridine). ${ }^{6}$ The benzyl groups of the btl ligand adopt a mutually anti conformation.

The packing of the cations in $[\mathbf{1}] \mathrm{Cl}$ appears to be dominated by 40 hydrogen bonding of the triazole ring. Each cation has four such triazole groups with four $\mathrm{C}-\mathrm{H}$ units capable of acting as $\mathrm{H}$-bond donors all of which are involved in hydrogen-bonding. These can be split into three distinct types: firstly, despite the presence of some disorder in the $\mathrm{Cl}^{-}$position, there is a $\mathrm{C}-\mathrm{H} . . . \mathrm{Cl}$ contact to 45 the chloride counter-ion $\left(\mathrm{d}_{\mathrm{C} . . \mathrm{Cl}}=3.410(9) \AA\right.$ (Fig. 3a)); secondly there is a $\mathrm{C}-\mathrm{H}$... O contact to the water solvate molecule $\left(\mathrm{d}_{\mathrm{C} \ldots \mathrm{O}}=\right.$ 3.33(1) ̊ (Fig. 3a)); finally the two remaining $\mathrm{C}-\mathrm{H}$ bonds are involved in $\mathrm{C}-\mathrm{H}$... N contacts to the triazole $\mathrm{N}(2)$ atom in other cations generating a chain parallel to the 011 direction with ${ }_{50} \mathrm{~d}_{\mathrm{C} \ldots \mathrm{N}}=3.398(6)-3.884(6) \AA$ (Fig. 3b). Indeed the disorder in the $\mathrm{Cl}^{-}$can be considered as potentially arising from competition between the preference for $\mathrm{C}-\mathrm{H} \ldots \mathrm{Cl}$ and $\mathrm{O}-\mathrm{H} . . . \mathrm{Cl}$ contacts with the $\mathrm{U}_{i j}$ of the $\mathrm{Cl}$ atoms elongated along the $\mathrm{O}-\mathrm{H}$ vector, potentially reflecting dynamic motion between the two H-bond 55 donors with a preference for the contact to water (3:2 ratio of site occupancy factors for Cl1A: Cl1B).
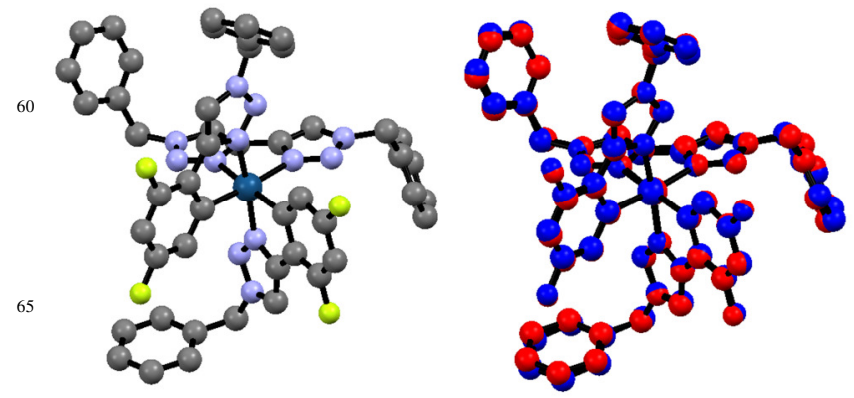

Figure 2 (left) structure of the cation, $\mathbf{1}^{+}$; (right) overlay of the $\mathbf{1}^{+}$cation in $[\mathbf{1}] \mathrm{Cl}$ and $[\mathbf{1}] \mathrm{PF}_{6}$ ( $\mathrm{H}$ atoms omitted for clarity).

Table 1. Selected bond lengths in $\AA$ and bond angles and dihedral angles in $\operatorname{deg}\left({ }^{\circ}\right)$ for $[\mathbf{1}] \mathbf{C l}$ and $[\mathbf{1}] \mathbf{P F}_{6}$.

\begin{tabular}{lll}
\hline & {$[\mathbf{1}] \mathbf{C l}$} & {$[\mathbf{1}] \mathbf{P F}_{\mathbf{6}}$} \\
\hline$\left(\mathrm{Ir}-\mathrm{C}_{\mathrm{dFphtl}}\right)$ & $2.023(4)$ & $2.021(7)$ \\
& $2.028(4)$ & $2.027(4)$ \\
$\left(\mathrm{Ir}-\mathrm{N}_{\mathrm{dFphtl}}\right)$ & $2.011(4)$ & $2.009(5)$ \\
& $2.029(4)$ & $2.030(5)$ \\
$\left(\mathrm{Ir}-\mathrm{N}_{\mathrm{btt}}\right)$ & $2.136(3)$ & $2.153(5)$ \\
& $2.144(4)$ & $2.156(4)$ \\
$\left(\mathrm{C}_{\mathrm{dFpht}}-\mathrm{Ir}-\mathrm{N}_{\mathrm{dFphtl}}\right)$ & $80.0(2)$ & $80.2(2)$ \\
& $80.3(2)$ & $80.3(2)$ \\
$\left(\mathrm{N}_{\mathrm{btt}}-\mathrm{Ir}-\mathrm{N}_{\mathrm{btt}}\right)$ & $76.3(1)$ & $76.0(2)$ \\
$(\mathrm{N}-\mathrm{C}-\mathrm{C}-\mathrm{N})_{\mathrm{btl}}$ & $1.7(6)$ & $0.6(8)$ \\
\hline
\end{tabular}

A search of the CSD revealed 476 structures containing 1,2,3triazole structures bearing $\mathrm{C}$ at $\mathrm{N}(1)$ and $\mathrm{H}$ at $\mathrm{C}(5)$. Of these 277 75 structures exhibited C-H...X $(X=N, O, S$, halogen $)$ contacts less than the sum of the van der Waals radii to formally anionic or merely electronegative atoms. ${ }^{17}$ Given the anion dependence of the bis-triazole $\mathrm{C}-\mathrm{H}{ }^{1} \mathrm{H}$ NMR resonance in polar $\mathrm{MeCN}$ solvent (which favours charge separation), the btl unit must be an 80 efficient $\mathrm{C}-\mathrm{H}$ hydrogen bond donor. 
Whilst the basicity of the triazole ring is well known and equilibria between $\mathrm{H}$ attachment at $\mathrm{N}(1)$ and $\mathrm{N}(2)$ have been reported, ${ }^{18}$ the role of the triazole ring to act as a hydrogen bond acceptor has only recently been described. ${ }^{19}$ Within the structures 5 of $[1] \mathrm{Cl}$ and $[\mathbf{1}] \mathrm{PF}_{6}$ the propensity for the dfPhtl triazole $\mathrm{C}-\mathrm{H}$ group to hydrogen bond to $\mathrm{N}(2)$ would indicate some H-bond acceptor character for $\mathrm{N}(2)$. Indeed each of the four crystallographically independent $\mathrm{N}(2)$ atoms in $[\mathbf{1}] \mathrm{Cl}$ appear involved in hydrogen bonding; Two are involved in the triazole ${ }_{10} \mathrm{C}-\mathrm{H} \ldots \mathrm{N}$ hydrogen bonding, which propagates parallel to the $b c$ diagonal (Fig. 3b) already described. A third forms a set of C$\mathrm{H}$... N contacts to the phenyl para-C-H of the benzyl substituent, generating chains parallel to the $a$-axis with $\mathrm{d}_{\mathrm{C} \ldots \mathrm{N}}=3.530(7) \AA$ whilst the last is involved in hydrogen bonding to the solvent 15 water $\left(\mathrm{d}_{\mathrm{O} \ldots \mathrm{N}}=3.18(1) \AA\right.$ ) (Fig. 4). A re-examination of the 476 original triazole structures revealed that 284 exhibited an $\mathrm{N}(2)$...H-C contact less than the sum of the van der Waals' radii.
Complex $[\mathbf{1}]\left[\mathrm{PF}_{6}\right]$ also crystallises in the triclinic space group $P-1$ 60 and exhibits similar packing features to $[\mathbf{1}] \mathrm{Cl}$. In $[\mathbf{1}] \mathrm{Cl}$ the btl ligand formed $\mathrm{C}-\mathrm{H}$ hydrogen bonds to the anion and a water solvate molecule whereas in $[\mathbf{1}]\left[\mathrm{PF}_{6}\right]$ there are a pair of $\mathrm{C}-\mathrm{H} \ldots \mathrm{F}$ contacts to the $\mathrm{PF}_{6}{ }^{-}$anion with $\mathrm{d}_{\mathrm{C} . . \mathrm{F}}=3.24(1)-3.538(9) \AA$ (Fig. 5a). The two crystallographically independent dFphtl triazole C${ }_{65} \mathrm{H}$ groups once again act as $\mathrm{C}-\mathrm{H}$ hydrogen bond donors, forming two $\mathrm{C}-\mathrm{H}$... $\mathrm{N}$ hydrogen bonds to $\mathrm{N}(2)$ of the btl ligand in an entirely analogous fashion to that in $[1] \mathrm{Cl}$ (Fig. 5b). The C...N distances at 3.308(7) and 3.32(1) $\AA$ are, on average, somewhat shorter than the average of those found in $[\mathbf{1}] \mathrm{Cl}(3.612(6) \AA)$ and, 70 in the case of $[1] \mathrm{PF}_{6}$ propagate parallel to the crystallographic $c$ axis. A comparison of the $\mathrm{C}-\mathrm{H}$ hydrogen bonding network in $[1] \mathrm{Cl}$ and $[1] \mathrm{PF}_{6}$ (Figs. 3 and 5) immediately reveals the similarities in these two structures.

The remaining two potential triazole $\mathrm{N}(2)$ hydrogen bond 75 acceptors on the dFphtl ligand form similar but longer contacts to
20

25 (a)

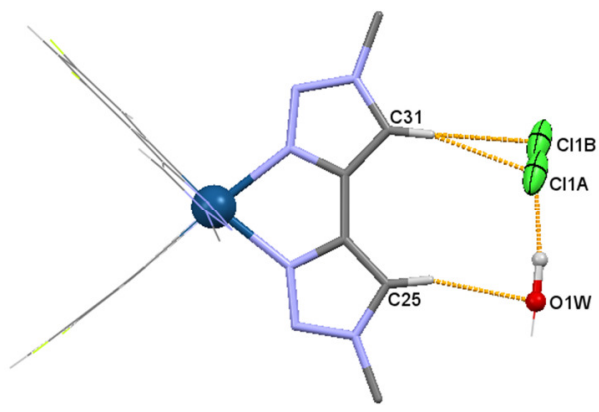

35

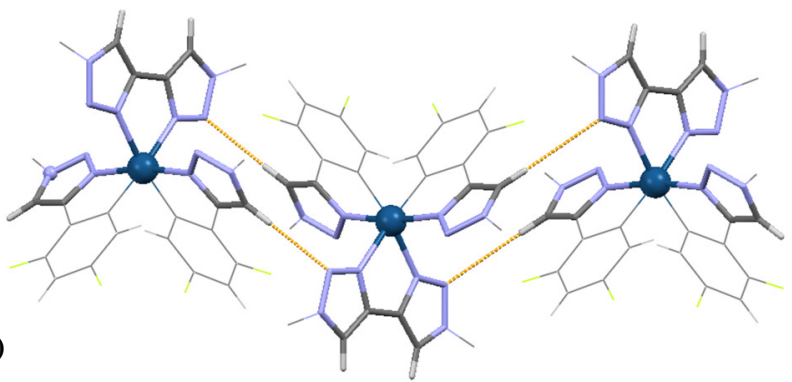

40

Figure 3. Triazole $\mathrm{C}-\mathrm{H}$ hydrogen bonding in $[1] \mathrm{Cl}$; (a) $\mathrm{C}-\mathrm{H} . . . \mathrm{Cl}$ and $\mathrm{C}-$ $\mathrm{H}$... O contacts to the counterion and water solvate molecule; (b) pairs of centrosymmetric $\mathrm{C}-\mathrm{H}$...N hydrogen bonds propagate parallel to the $b c$ diagonal (phenyl rings of the benzyl groups omitted for clarity).

45

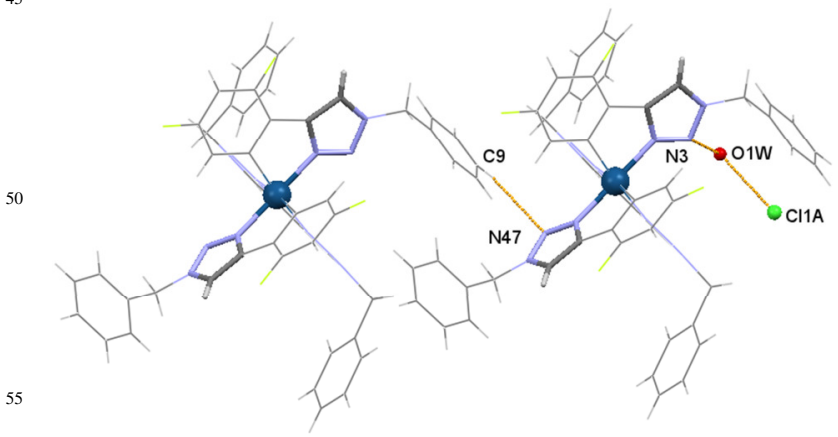

Figure 4. Triazole $\mathrm{N}(2)$ hydrogen bonding in $[\mathbf{1}] \mathrm{Cl}$ comprise N...H-C and $\mathrm{N}$... H-O contacts. (a)

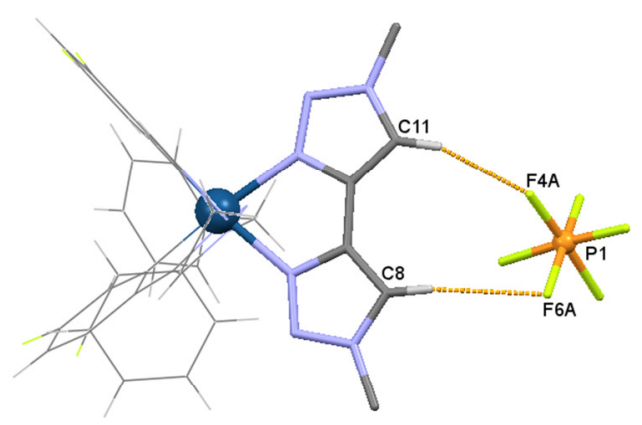

90

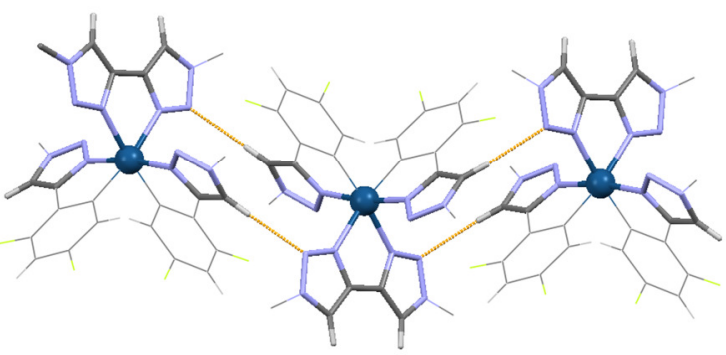

Figure 5. Triazole $\mathrm{C}-\mathrm{H}$ hydrogen bonding in $[\mathbf{1}]\left[\mathrm{PF}_{6}\right]$; (a) $\mathrm{C}-\mathrm{H}$...F 100 contacts to the counterion; (b) pairs of centrosymmetric C-H...N hydrogen bonds propagate parallel to the $c$ axis (phenyl rings of the benzyl groups omitted for clarity).

105

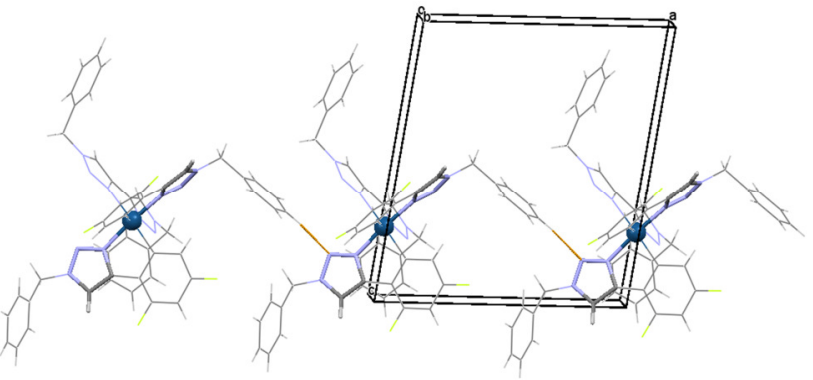

115

Figure 6. Weak C-H...N hydrogen bonds in $[\mathbf{1}]\left[\mathrm{PF}_{6}\right]$ propagate parallel to the $a$ axis. 
those observed in $[\mathbf{1}] \mathrm{Cl}$. Specifically, the $p$-phenyl $\mathrm{C}-\mathrm{H}$ of the benzyl group in $[\mathbf{1}]\left[\mathrm{PF}_{6}\right]$ forms markedly longer contacts $\left(\mathrm{d}_{\mathrm{C} \ldots \mathrm{N}}=\right.$ $3.68(1) \AA)$ compared to $3.350(7)$ in $[\mathbf{1}] \mathrm{Cl}$. In $[1] \mathrm{PF}_{6}$ these propagate parallel to the crystallographic $a$-axis (Fig. 6).

\section{Discussion}

The propensity for the $\mathrm{C}-\mathrm{H}$ bond of the triazole ring to participate in hydrogen bonding appears to lend itself favourably to some degree of control of solid-state architectures and may be an 10 appropriate supramolecular synthon for the design of complex solid state architectures. Notably, in both $[\mathbf{1}] \mathrm{Cl}$ and $[\mathbf{1}]\left[\mathrm{PF}_{6}\right]$ the structures appear to adopt similar packing motifs that facilitate hydrogen bonding between cations and generate large void channels which accommodate the counter-ions and lattice solvent 15 molecules.

The propensity for $\mathbf{1}^{+}$to adopt packing modes that appear to optimise $\mathrm{C}-\mathrm{H}$ hydrogen bonds to the triazole ring and, to a lesser extent, offer the potential for E-H...N contacts to the basic $\mathrm{N}(2)$ atom was intriguing. A search of the CSD for other metal20 coordinated triazole derivatives afforded 93 transition metal complexes; of which 43 exhibited C-H...E contacts less than the sum of the van der Waals radii to the triazole ring. Of these 6 structures exhibited some similarity to $\mathbf{1}^{+}$in that they exhibited (i) octahedral coordination at the transition metal; (ii) at least two 25 pendant triazole rings bound via a bidentate or tridentate donor and; (iii) at least one counter-anion $\left(\mathrm{ClO}_{4}^{-}, \mathrm{PF}_{6}^{-}\right.$or $\left.\mathrm{BF}_{4}^{-}\right){ }^{20} \mathrm{In}$ each case every triazole $\mathrm{C}-\mathrm{H}$ unit exhibited a close $\mathrm{C}-\mathrm{H}$...X contact to the anion, suggesting that such $\mathrm{C}-\mathrm{H}$...X cation... anion contacts may be a reliable synthon for constructing well-defined 30 architectures. In the case of both $[\mathbf{1}] \mathrm{Cl}$ and $\left.[\mathbf{1}] \mathrm{PF}_{6}\right]$ the large number of triazole functionalities (four per cation) permit the formation of cation...anion $\mathrm{C}-\mathrm{H}$...X hydrogen bonds as well as cation...cation $\mathrm{C}-\mathrm{H}$... $\mathrm{N}$ hydrogen bonds. Whilst the thermal stabilities of $[\mathbf{1}] \mathrm{Cl}$ and $[\mathbf{1}] \mathrm{PF}_{6}$ appear high $\left(\mathrm{mp}>250{ }^{\circ} \mathrm{C}\right)$, 35 derivatives with the btl ligand appear photo-chemically unstable. $^{11 \mathrm{c}, 21}$ However, this does not appear to be a general phenomenon with triazoles and appears specifically associated with the btl ligand. $^{22}$ Further studies on other triazole-based ligands are underway.

\section{${ }_{40}$ Conclusions}

The structures of $[\mathbf{1}] \mathrm{Cl}$ and $[\mathbf{1}]\left[\mathrm{PF}_{6}\right]$ exhibit similar propensities for $\mathrm{C}-\mathrm{H} \ldots \mathrm{X}$ and $\mathrm{E}-\mathrm{H} \ldots \mathrm{N}$ hydrogen bonding to the triazole framework. Whilst the btl ligand leads to photochemical instability it appears to exhibit particularly strong C-H...X ${ }_{45}$ hydrogen-bonding interactions which are retained in solution. The potential to tailor the anion and resultant ion...ion interactions in a coherent fashion may permit some control over the solid state architecture of such $[\mathbf{1}]^{+}$salts in order to optimise response. Further studies to implement cation....anion and 50 cation...cation hydrogen-bonding in other $\mathrm{Ir}^{\mathrm{III}}$ triazole complexes are underway.

\section{Experimental}

1-benzyl-4-(2,4-difluorophenyl)-1H-1,2,3-triazole, $\mathrm{dFphtl},{ }^{23}$ and 1,1'-bis(phenylmethyl)-4,4'-Bi-1H-1,2,3-triazole, bt, ${ }^{11 \mathrm{c}}$ were ${ }_{55}$ prepared according to the literature methods.
Preparation of Iridium(III) Bis[1'-(4',6'-difluorophenyl)1,2,3triazolato-N, $\left.\mathrm{C}^{2}\right]-1,1^{\prime}$-bis(phenylmethyl)-4,4'-Bi-1H-1,2,3triazole Chloride, [1]Cl

dFphtl (2.20 equiv.) was mixed with $\mathrm{IrCl}_{3} \cdot 6 \mathrm{H}_{2} \mathrm{O}$ (1.00 equiv.) in a 60 mixture of 2-ethoxyethanol and water $(6 / 1 \mathrm{v} / \mathrm{v})$ to reach a concentration in $\mathrm{IrCl}_{3} \cdot 6 \mathrm{H}_{2} \mathrm{O}$ of $0.04 \mathrm{M}$. The mixture was degassed by multiple vacuum and $\mathrm{N}_{2}$ purging cycles. The suspension was heated at $130{ }^{\circ} \mathrm{C}$ for $24 \mathrm{~h}$. A yellow precipitate formed and was collected by filtration and used without further 65 purification. To this solid was added the btl ligand (1.10 equiv.) and 2-ethoxyethanol was added to reach a concentration in iridium of $0.04 \mathrm{M}$. The mixture was degassed by multiple vacuum and $\mathrm{N}_{2}$ purging cycles. The suspension was heated at 130 ${ }^{\circ} \mathrm{C}$ for $24 \mathrm{~h}$ and the reaction mixture was cooled to room 70 temperature. The compound was precipitated with $\mathrm{Et}_{2} \mathrm{O}$ and dried under vacuum. The crude solid was purified by flash chromatography on silica gel using DCM/acetone (9/1) to DCM/acetone $(9 / 1)+5 \% \mathrm{MeOH} .{ }^{1} \mathrm{H}$ NMR $\left(400 \mathrm{MHz}, \mathrm{CD}_{3} \mathrm{CN}\right)$ $\delta$ (ppm): 8.66 (s, 2H), 8.22 (s, 2H), 7.32-7.36 (m, 12H) ), 7.17$757.23(\mathrm{~m}, 8 \mathrm{H}), 6.57(\mathrm{td}, J=9.6,2.0 \mathrm{~Hz}, 2 \mathrm{H}), 5.70(\mathrm{dd}, J=8.8,2.0$ $\mathrm{Hz}, 2 \mathrm{H}), 5.60(\mathrm{~s}, 4 \mathrm{H}), 5.53(\mathrm{~d}, J=2.4 \mathrm{~Hz}, 4 \mathrm{H})$. Crystals of $[\mathbf{1}] \mathrm{Cl}$ were obtained from a mixed solution of propionitrile and tertbutyl methyl ether.

\section{${ }_{80}$ Preparation of Iridium(III) Bis[1'-(4',6'-difluorophenyl)1,2,3- triazolato-N, ${ }^{2}$ ]-1,1'-bis(phenylmethyl)-4,4'-Bi-1H-1,2,3- triazole, hexafluorophosphate $[1] \mathrm{PF}_{6}$}

[1]Cl was dissolved in a minimum amount of acetonitrile and a 85 solution of aqueous $\mathrm{NH}_{4} \mathrm{PF}_{6}(10$ equiv., $1.0 \mathrm{~g} / 10 \mathrm{~mL})$ was added dropwise to cause the precipitation of a white solid. The suspension was cooled to $0{ }^{\circ} \mathrm{C}$ for $1 \mathrm{~h}$, filtered and the resulting solid was washed with cold water then $\mathrm{Et}_{2} \mathrm{O}$ and purified by flash chromatography on silica gel using DCM/acetone (9/1). The 90 analytical data matches that reported previously. ${ }^{11 \mathrm{c}}$ White solid. Yield: 36\%. R: 0.3 (DCM/Acetone 85/15; Silica). ${ }^{1} \mathrm{H}$ NMR (400 $\left.\mathrm{MHz}, \mathrm{CD}_{3} \mathrm{CN}\right) \delta(\mathrm{ppm}): 8.31(\mathrm{~s}, 2 \mathrm{H}), 8.16(\mathrm{~d}, J=1.6,2 \mathrm{H}), 7.16-$ $7.38(\mathrm{~m}, 20 \mathrm{H}), 6.59(\mathrm{td}, J=9.2,2.0 \mathrm{~Hz}, 2 \mathrm{H}), 5.71(\mathrm{dd}, J=8.8$, $2.4 \mathrm{~Hz}, 2 \mathrm{H}), 5.58(\mathrm{~d}, J=2.8,4 \mathrm{H}), 5.51(\mathrm{~d}, J=1.2,4 \mathrm{H}) .{ }^{19} \mathrm{~F}$ ${ }_{95} \mathrm{NMR}\left(376 \mathrm{MHz}\right.$, Acetone- $\left.\mathrm{d}_{6}\right) \delta$ (ppm): -72.3 (d, $\left.J=707 \mathrm{~Hz}, 6 \mathrm{~F}\right)$, 110.9 (q, $J=9 \mathrm{~Hz}, 2 \mathrm{~F}),-113.2$ (t, $J=10 \mathrm{~Hz}, 2 \mathrm{~F})$. HR-MS (ES-QTOF $)\left(\mathrm{C}_{48} \mathrm{H}_{36} \mathrm{~F}_{4} \mathrm{~N}_{12} \mathrm{Ir}^{+}\right)$Calculated: 1049.2749; Experimental: 1049.2737

\section{${ }_{100}$ Crystallography}

A colourless block of $[\mathbf{1}] \mathrm{Cl} \cdot \mathrm{H}_{2} \mathrm{O} \cdot 2 \mathrm{PrCN}\left(\mathrm{C}_{54} \mathrm{H}_{48} \mathrm{ClF}_{4} \mathrm{IrN}_{14} \mathrm{O}\right.$, MW $=1212.71$ ) was examined on a Bruker APEX-II CCD at 130(2) $\mathrm{K}$ using Mo-K $\alpha$ radiation $(\lambda=0.71073 \AA)$ and an Oxford cryostream variable temperature device. Data were collected 105 using phi and omega scans using the APEX-II software. ${ }^{24} \mathrm{~A}$ triclinic unit cell $(a=12.4555(10), b=14.7313(12), c=$ 15.9151(12) $⿱ ㇒, \alpha=63.621(2), \beta=81.425(2), \gamma=83.341(2)^{\circ}, V=$ 2582.8(4) $\AA^{3}$ ) was determined from 9870 reflections measured in the range $4.62<2 \theta<60.78^{\circ}{ }^{25}$ A total of 30645 reflections were 110 measured $\left(\mathrm{R}_{\mathrm{int}}=0.051\right)$ of which 10619 were unique with 9048 unique reflections exhibiting $I>2 \sigma(I)$, Data were corrected for absorption (SADABS). ${ }^{26}$ The structure was initially solved by direct methods ${ }^{27}$ in the $P 1$ space group with $Z^{\prime}=2$ and one $\Lambda$ and 
one $\Delta$ form of $\mathbf{1}^{+}$per asymmetric unit. Subsequently an inversion centre was located (ADDSYM within PLATON) ${ }^{28}$ and the final structure (with $Z^{\prime}=1$ ) refined against $F^{2}$ to yield $R_{1}(I>2 \sigma(I))=$ 0.037 and $w R_{2}$ (all data) $=0.089, S=1.049$. Residual electron 5 density in the final difference map was within $+1.99 /-1.24 \mathrm{e} \AA^{-3}$. CCDC deposit number 1001893.

\section{Notes and references}

${ }^{a}$ Department of Chemistry and Biochemistry, The University of Windsor, 401 sunset Avenue, Windsor, ON, Canada N9B 3P4; Tel: +1 519253

103000 ext 3700; E-mail jmrawson@uwindsor.ca

${ }^{b}$ Département de Chimie, Université de Sherbrooke, 2500 Boul. de

l'Université, Sherbrooke, QC, Canada, J1K $2 R 1$.

${ }^{c}$ EaStCHEM School of Chemistry, University of St Andrews, St Andrews, Fife, UK, KY16 9ST, Fax: +44-1334 463808; Tel: +44-1334 463826; E-

15 mail: eli.zysman-colman@st-andrews.ac.uk; URL: http://www.zysman-

colman.com

$\dagger$ Electronic Supplementary Information (ESI) available: Structural data for [1]Cl and [1]PF 6 in cif format. See DOI: $10.1039 / \mathrm{b} 000000 \mathrm{x} /$

1 (a) V.D. Bock, H. Hiemstra and J.H. van Maarseveen, Eur. J. Org. Chem., 2006, 51; (b) M. Meldal and C.W. Tornoe, Chem. Rev., 2008, 108, 2952; (c) J.E. Hein and V.V. Fokin, Chem. Soc. Rev., 2010, 39, 1302; (d) B. Schulze and U.S. Schubert, Chem. Soc. Rev., 2014, 43, 2522 .

2 R. Huisgen, Angew. Chem. Int. Ed. Engl., 1963, 2, 565.

3 C. Hartmuth, M.G. Kolb, K. Finn and B. Sharpless, Angew. Chem. Int. Ed., 2001, 40, 2004.

4 S. Beckendorf, S. Asmus, C. Muck-Lichtenfeld and O.G. Mancheno, Chem. Eur. J., 2013, 19, 1581.

5 S. Lee, Y. Hua, H. Park and A.H. Flood, Org. Lett., 2010, 12, 2100.

6 B. Sui, B. Kim, Y. Zhang, A. Frazer and K. D. Belfield, Appl. Mater. Interf, 2013, 5, 2920.

7 (a) H. Yersin, Highly Efficient OLEDs with Phosphorescent Materials, Wiley-VCH, Weinheim, 2008; (b) R. D. Costa, E. Ortí, H. J. Bolink, F. Monti, G. Accorsi and N. Armaroli, Angew. Chem. Int. Ed., 2012, 51, 8178 .

8 S. Reineke, T.C. Rosenow, B. Lüssem and K. Leo, Adv. Mater., 2010, 22, 3189

9 E. Zysman-Colman, J. D. Slinker, J. B. Parker, G. G. Malliaras and S. Bernhard, Chem. Mater., 2008, 20, 388.

10 C.H.Shin, J.O. Huh, M. H. Lee and Y. Do, Dalton Trans, 2009, 6476.

11 (a) K.N. Swanick, S. Ladouceur, E. Zysman-Colman and Z. Ding, Chem. Commun., 2012, 48, 3179; (b) K.N. Swanick, S. Ladouceur, E. Zysman-Colman, Z. Ding, Angew. Chem.. Int. Ed., 2012, 51, 11079; (c) L. Donato, P. Abel and E. Zysman-Colman, Dalton Trans., 2013, 42, 8402; (d) J. M. Fernández-Hernández, S. Ladouceur, Y. Shen, A. Iordache, X. Wang, L. Donato, S. Gallagher-Duval, M. de Anda Villa, J. D. Slinker, L. De Cola and E. Zysman-Colman J. Mater. Chem. C, 2013, 1, 7440; (e) S. Ladouceur, K.N. Swanick, S. Gallagher-Duval, Z. Ding and E. Zysman-Colman, Eur. J. Inorg. Chem., 2013, 5329; (f) S. Ladouceur, D. Fortin and E. ZysmanColman, Inorg. Chem. 2011, 50, 11514

12 A.P. Wilde and R.J. Watts, Inorg. Chem., 2011, 50, 11514.

13 H. Rudmann, S. Shimada, M.F. Rubner, D.W. Oblas and J.E. Whitten, J. Appl. Phys. 2002, 92, 1576.

14 (a) F. G. Gao and A.J. Bard, J. Am. Chem. Soc., 2000, 122, 7426; (b) Q. Zhang, Q. Zhou, Y. Cheng, L. Wang, D. Ma, X. Jing and F. Wang, Adv. Funct. Mater., 2006, 16, 1203.

15 G. E. Schneider, H. J. Bolink, E.C. Constable, C. D. Ertl, C. E. Housecroft, A. Pertegàs, J. A. Zampese, A. Kanitz, F. Kessler and S. B. Meier, Dalton Trans., 2014, 43, 1961.

16 Z.-P. Deng, H.-L. Qi, L.-H. Huo, H. Zhao and S. Gao, CrystEngComm, 2011, 13, 6632.

17 A search of the CSD (2013 release) using Conquest v1.16 (www.ccdc.cam.ac.uk)
18 J.-L. M. Abboud, C. Foces-Foces, R. Notario, R. E. Trifonov, A. P. Volovodenko, V. A. Ostrovskii, I. Alkorta and J. Elguero, Eur. J. Org. Chem., 2001, 3013.

19 B. Schulze and U.S. Schubert, Chem. Soc. Rev., 2014, 43, 2522.

20 (a) W.-W. Yang, J. Yao and Y.-W. Zhong, Organomet. , 2012, 31, 8577; (b) E.C. Constable, C.E. Housecroft, J.R. Price, L. Schweighauser and J.A. Zampese, Inorg.Chem.Commun. 2010, 13, 495; (c) D. Schweinfurth, F. Weisser, D. Bubrin, L. Bogani and B. Sarkar, Inorg.Chem. 2011, 50, 6114; (d) D. Schweinfurth, S. Demeshko, M.M. Khusniyarov, S. Dechert, V. Gurram, M.R. Buchmeiser, F. Meyer and B. Sarkar, Inorg.Chem. 2012, 51, 7592.

21 C. E. Welby, L. Gilmartin, R. R. Marriott, A. Zahid, C. R. Rice, E. A. Gibson and P. I. Elliott, Dalton Trans, 2013, 42, 13527.

22 (a) C. E. Welby, G. K. Armitage, H. Bartley, A. Sinopoli, B. S. Uppal and P. I. Elliott, Photochem Photobiol Sci, 2014, 13, 735; (b) C. E. Welby, C. R. Rice and P. I. Elliott, Angew Chem Int Ed Engl, 2013, 52, 10826.

23 S. Ladouceur, A.M. Soliman and E. Zysman-Colman, Synthesis 2011, 2011, 3604.

24 APEX-II, Bruker AXS, Madison, Wisconsin, USA.

25 SAINT v7.58A, Bruker AXS, Madison, Wisconsin, USA

26 SADABS, Bruker AXS, Madison, Wisconsin, USA.

27 SHELXTL-2013, Bruker AXS, Madison, Wisconsin, USA.

28 PLATON, A.L. Spek, Acta Cryst., 2009, D65, 148. 